\section{Enzyme biochemistry}

Chemistry and Control of Enzyme Reactions. By K. G. Scrimgeour. Pp. 633. (Academic: London and New York, 1977.) $£ 24.50 ; \$ 47.90$.

Tuis book attempts to cover, in a single volume, most aspects of the biochemistry of enzymes, from structure and mechanism to metabolic regulation, from purification to chemotherapy. The scope is laudable; the execution must, however, be faulted.

A reviewer of a book of this length (over 600 pages) ought not to have to quibble with its balance. Yet we find 30 pages devoted to the pterin coenzymes and a page-and-a-half to the principles of rapid-reaction techniques, 10 pages to the ferredoxins, and no description (apart from a reference elsewhere) of how to measure $K_{i}$ for a reversible inhibitor. a physical science. By adopting an avowedly descriptive approach, Dr Scrimgeour fails to bring out the growing precision in the study of enzyme structure and mechanism that has been the hallmark of the past 10 years of collaboration by X-ray crystallographers, protein chemists, organic chemists and kineticists. Many of the facts are there but the message is blunted.

The discursive nature of the book works better in descriptions of the biological significance and background of
Molecular enzymology is effectively

the many enzymes used as examples. For example, in the chapter on "Metals and Enzymes", the account of nitrogen fixation does not ignore its economic and biological importance. Few aspects of enzymology are left unmentioned, the final chapter of the book ranging from hormone action mediated by cyclic AMP, to repression of enzyme synthesis in bacteria, and finishes with chemical theories of taste and smell

Dr Scrimgeour achieves his aim of using straightforward English. $\mathrm{He}$ writes with enthusiasm and obvious affection for enzymes in all their guises. I have already pointed out my own preference for a more analytical approach. I would also have liked a more critical stance. Too often I had the impression that a published result was included without due heed being paid to its weight or reliability, though this does add to the undeniable value of the book as a source of references.

The book is nicely turned out, with few mistakes or misprints. It is too long and detailed in some areas and lacks the nccessary balance for it to be commmended to undergraduates or research students as a teaching book. Add to that its high price and its likely future as a source book worth dipping into for its references (comprehensive up to 1975) and its more descriptive passages becomes clear.

Richard Perham

R. N. Perham is Reader in the Department of Biochemistry at the University of Cambridge, UK.

\section{Topics in geography}

Contemporary Problems in Geography. Three new volumes. (Clarendon/Oxford University Press: Oxford, London and New York, 1977.) Hardback each $£ 6.50$; paperback £3.

THE Editors of this new series (of which one volume--Mathematics for Geographers and Planners by A. G. Wilson and M. J. Kirkby-has already appeared) make its purpose very clear: to provide up-to-date, concise reviews of selected topics (not problems as they state) in geography, at a level suitable for first- and second-year undergraduates who have done little or no specialised geography before, and who need a broad understanding of an area which will fit in with other aspects of geography and environmental science. The three volumes under review were apparently designed also to fill the acknowledged gap in the available literature between advanced texts written and water flow and their cycling systems are not treated in depth; thus, the book title is misleading. The difficulties faced were the need to make bold generalisations about the whole system yet retain accuracy over specific points. The method adopted is to treat each selected component of soil and vegetation systems in turn in the hope of building up a sequential picture towards the end of the book. Unfortunately, this hope has not been achieved.

The first section of the book deals with general problems of understanding and explanation and how these may be tackled using models. In the second part of the book, four chapters deal with nutrient systems: weathering processes, atmospheric inputs, leaching and cycling. Only calcium, magnesium, potassium and silicon are treated at all fully; nitrogen, carbon, phosphorous, trace elements energy and water are not dealt with in detail. In the third part of the book, two chapters deal with some of these systems as functional entities. Overall, the author states that the book is concerned more with ideas and concepts; thus, it is neither a factual reference text nor a comprehensive treatment of what its title would suggest. The treatment is in parts most uneven, the writing turgid and the 'bold generalisations' largely absent. A certain basic knowledge of soil, weathering, vegetation and hydrology is asssumed.

The layout differs somewhat from the other two books in the series, with fewer references at chapter ends, less helpful and selective comment on these, and distracting cross referencing in the chapters themselves. The chapters generally begin with the more complex notions and conclude with the simplest models; and these are not original but standard. Surely at this level, the reverse procedure should have been adopted - that is, the simple model, its underlying assumptions, its inadequacies, suggestions for its improvement, followed by discussion and conclusions.

Clearly, organic cycling and water cycling should have been dealt with. Overall the structure of the book is weak, it reads still like a set of lecture notes. And I, for one, wish that the Editor's loyalty and patience had been troubled by several more drafts than the vast number alluded to. But who these days has infinite patience and infinite time? The first bold (and unsubstantiated) generalisation appears on p35. For many sections, vastly more accurate, informed, well-expressed reviews can be cited. The text lacks authority and coherence; there is a desire to impress by the citing of numerous references, but accuracy over detail has submerged the initial stated aims. 